ORIGINAL ARTICLE

ARTIGO ORIGINAL

\section{Rotational thromboelastometry in the perioperative period of cardiac surgeries: cost-effectiveness analysis and budget impact}

\author{
Tromboelastometria rotacional no período perioperatório de \\ cirurgias cardíacas: custo-efetividade e impacto orçamentário
}

André Soares Santos ${ }^{1,2}$, Ananda Jessyla Felix Oliveira1,3, Magda Lourenço Fernandes ${ }^{4,5}$, José Luiz dos Santos Nogueira', Kenya Valéria Micaela de Souza Noronha², Mônica Viegas Andrade²

DOI: $10.21115 / J B E S . v 12 . n 3 . p 173-88$

\section{Keywords}

thrombelastography, blood coagulation, thoracic surgery, biomedical technology assessment, cost-effectiveness evaluation

\section{Palavras-chave:}

tromboelastografia, coagulação sanguínea, cirurgia torácica, avaliação da tecnologia biomédica, avaliação de custo-efetividade

\begin{abstract}
Objective: The transfusion of blood components and blood products in cardiac surgery patients can be guided by protocols based on standard laboratory tests and/or clinical decisions (Standardof-Care, SOC) or viscoelastic haemostatic assays (VHA). The aim of this study is to evaluate the cost-effectiveness and budget impact of VHAs compared to SOC. Methods: A decision tree model was built in TreeAge Pro 2009. Costs and benefits were taken from the medical literature. The costeffectiveness was evaluated in a base-case scenario and a worst-case scenario, considering low costs of adverse events. The budget impact was evaluated from data taken from Datasus. Cost data were measured in 2019 USD and outcomes were measured in QALYs. Results: VHAs were considered dominant in the base-case scenario and very cost-effective in the worst-case scenario (ICER = \$ 1,083.21 USD/QALY). The budget impact analysis varied from a cost-saving result in the base-case scenario to a reasonable increase in cost in the worst-case scenario. Since the total market share of the technology is unlikely, a reasonable estimative for the base-case scenario and the worst-case scenario are about - $\$ 275$ million USD and $\$ 132$ million USD, respectively. Conclusion: We conclude that the VHAs are cost-effective and should be recommended for the use in the perioperative period of cardiac surgeries, especially for patients with a high risk of hemorrhage or coagulation problems.
\end{abstract}

\section{RESUMO}

Objetivo: A transfusão de sangue, hemocomponentes e produtos sanguíneos em pacientes submetidos a cirurgia cardíaca pode ser guiada por protocolos baseados em testes laboratoriais padrão e/ou decisão clínica (Standard-of-Care, SOC) ou testes viscoelásticos (TVEs). O objetivo deste estudo é avaliar o custo-efetividade e o impacto orçamentário dos TVEs em comparação com o SOC. Métodos: Um modelo de árvore de decisão foi construído em TreeAge Pro 2009. Os parâmetros de custos e benefícios foram obtidos da literatura médica. A relação custo-efetividade foi avaliada em um cenário-base e no pior cenário, considerando baixos custos de eventos adversos. O impacto orçamentário foi avaliado a partir de dados extraídos do Datasus. Os custos foram avaliados em USD 2019 e os desfechos em AVAQs. Resultados: Os TVEs foram considerados dominantes no cenário-base e muito custo-efetivos no pior cenário avaliado (RCEI =1.083,21 USD/QALY). A análise de im-

Received on: 03/26/2020. Approved for publication on: 10/16/2020

1. Health Technology Assessment Center of the UFMG Teaching Hospital (NATS-HC/UFMG) - Federal University of Minas Gerais, Belo Horizonte, MG, Brazil.

2. Department of Economics, School of Economical Sciences, Federal University of Minas Gerais, Belo Horizonte, MG, Brazil.

3. Department of Applied Nursing, Nursing School, Federal University of Minas Gerais, Belo Horizonte, MG, Brazil.

4. Teaching Hospital, Federal University of Minas Gerais, Belo Horizonte, MG, Brasil.

5. Santa Casa de Belo Horizonte, Belo Horizonte, MG, Brasil.

Institution where the work was conducted: Federal University of Minas Gerais, Belo Horizonte, MG, Brasil.

Funding: This study was funded by the Brazilian research promoting organizations Conselho Nacional de Desenvolvimento Científico e Tecnológico (CNPq; processo 381587/2018-5) and Instituto de Avaliação de Tecnologias em Saúde (IATS). No pharmaceutical industries contributed with resources for this study.

Potential conflicts of interest: The authors declare to have no conflicts of interest that could influence the results. Congresses where the study was presented: This study was not yet presented in any event.

Corresponding author: André Soares Santos. Department of Economical Sciences, School of Economical Sciences, Room 2064, Universidade Federal de Minas Gerais. Av. Presidente Antônio Carlos, 6.627, Pampulha, Belo Horizonte, MG, Brazil. CEP: $31270-901$.

Telephone: +55 (31) 99180-8788. E-mail: andresantos111@ufmg.br 
pacto orçamentário variou de um resultado de economia de custos no cenário-base a um aumento razoável no custo no pior cenário. Como a hipótese de que a tecnologia será adotada para toda a demanda do mercado é improvável, estimativas razoáveis para o cenário-base e o pior cenário são de aproximadamente -275 milhões de USD e 132 milhões de USD, respectivamente. Conclusão: Concluímos que os VHAs são econômicos e devem ser recomendados para uso no período perioperatório de cirurgias cardíacas, principalmente para pacientes com alto risco de problemas de hemorragia ou coagulação.

\section{Introduction}

Cardiovascular diseases (CVDs) have become a major concern in Brazil due to population aging and a high prevalence of chronic diseases, such as diabetes and hypertension (Brasil, 2011; Prince et al., 2015; Santos et al., 2015; Theme Filha et al., 2015; Souza \& Peixoto, 2017; Massa et al., 2019). Specifically, ischemic heart disease and cerebrovascular diseases were the two main causes of death in 2017, with mortality rates of 80.0 and 56.6 per 100.000 inhabitants, respectively (DANTPS/ SVS/MS, 2019). Myocardial revascularization using cardiopulmonary bypass (CPB) with 2 or more grafts was the most common cardiovascular surgery performed between 2009 and 2018 in Brazil (Brasil, 2019). By diverting blood and providing a bloodless surgical field, CPB allows the manipulation of the patient's heart (Souza \& Elias, 2006; Braile, 2010). However, the patient who undergoes cardiac surgery, especially with $\mathrm{CPB}$, may experience massive blood losses due to non-surgical causes, surgical causes or coagulation disorders. If not controlled, massive bleeding can contribute to increased patient morbidity and mortality (Miana et al., 2004; Whitlock et al., 2005; Santos et al., 2007; Costa et al., 2012; Wikkelsø et al., 2016; Lodewyks et al., 2018). The control of massive bleeding is achieved through the transfusion of blood, blood products, and blood components.

The transfusion of blood components and blood products such as red blood cells (RBCs), fresh frozen plasma (FFP), fibrinogen, cryoprecipitate, platelets, and coagulation factors can be directed by algorithms based on routine laboratory tests and/or clinical decision (which will be jointly referred to as SOC, Standard-of-Care) or viscoelastic haemostatic assays (VHAs) (Bolliger \& Tanaka, 2013; Wikkelsø et al., 2016). Although laboratory tests are widely available, the response time with the use of these tests can reach 45 to 60 minutes and the delay in conduct reduces its usefulness in the urgent treatment of coagulopathies (Craig et al., 2008; Benes et al., 2015; Wikkelsø et al., 2016; Wikkelsø et al., 2017; Lodewyks et al., 2018). It is also argued that the prothrombin time (PT) and activated partial thromboplastin time (aPTT) tests are weak predictors of bleeding in critically ill patients (Lier et al., 2013). In addition, studies indicate that 15 to $50 \%$ of all allogeneic blood transfusions are inappropriate and the conduct regarding transfusion is highly variable between health services (Görlinger et al., 2013).

VHAs have increased their representativeness because of their capacity to distinguish between the most important coagulopathies, such as thrombocytopenia, deficiency of coagulation factors, heparin effect, hypofibrinogenemia and hyperfibrinolysis, and the possibility of a targeted, individualized and timely intervention (Craig et al., 2008; Benes, et al., 2015). With the use of VHAs close to the patient, the response time can drop to 15 to 20 minutes, with some tests being ready within five minutes (Görlinger et al., 2013; Lodewyks et al., 2018). The rapid and comprehensive results made VHAs popular to monitor the coagulation in patients undergoing cardiac surgery, liver transplantation and obstetric procedures (Wang et al., 2010). In addition to the faster intervention, these tests are associated with a reduction in the amount of allogeneic products used in patients, with potential clinical benefit (Wikkelsø et al., 2016; Fahrendorff et al., 2017; Serraino \& Murphy, 2017; Wikkelsø et al., 2017; Lodewyks et al., 2018).

Cardiac surgeries are the biggest consumers of blood products (Horvath et al., 2013). Transfusion of allogeneic blood products, despite its importance in saving patients' lives, has been associated with adverse outcomes such as increased chance of infections, thromboembolic events, acute kidney injury (AKI), pulmonary complications, sepsis and mortality in patients undergoing surgical procedures (Engoren et al., 2002; Dellinger \& Anaya, 2004; Murphy et al., 2007; Aronson et al., 2008; Marik \& Corwin, 2008; Glance et al., 2011; Bhaskar et al., 2012; Santos et al., 2013). There is some disagreement in the literature about the causality of this relationship (Murphy et al., 2007, 2015; Andrade, 2017; Serraino \& Murphy, 2017). Nonetheless, authors suggest that all possible measures to reduce the unnecessary or inappropriate use of allogeneic products should be taken (Görlinger et al., 2013).

Despite this controversy, recent systematic reviews have shown some interesting advantages in terms of final outcomes with the use of VHAs during various types of procedures, including cardiac surgeries, but the result is not stable throughout the studies (Wikkelsø et al., 2016; Fahrendorff et al., 2017; Serraino \& Murphy, 2017; Lodewyks et al., 2018). We conducted a systematic review and found some advantages for patients with the use of the VHAs. Specially, mortality (3.4\% vs. 6.8\%; $\mathrm{RR}=0.50,95 \% \mathrm{Cl}=0.26-0.96$, $\mathrm{p}$-value $=0.04$; $\mathrm{I}^{2}=1 \%, \mathrm{p}$-value $=0.40 ; 689$ patients, seven studies; fixed-effects model) and the risk of acute kidney failure seem to be reduced in clinical relevant levels (10.5\% vs. 17.6\%; $R R=0.56$, $95 \% \mathrm{IC}=0.36-0.87, \mathrm{p}$-value $=0.009 ; \mathrm{I}^{2}=0 \%, \mathrm{p}$-value $=0.43$; 449 participants, five studies; fixed-effects model).

The costs of cardiac surgeries are significant for the public system in Brazil (Siqueira et al., 2017; Stevens et al., 2018). An estimative show that the cost of cardiac surgeries in Brazil is 
between $15,675.81$ to $24,994.18$ USD, depending on the severity of the case (Titinger et al., 2015). Despite being more efficacious for the management of transfusions, the VHA-based protocols are expected to add an extra cost to the procedure. So, in many health services, transfusion is still guided by SOC. Given the apparent relevance of the technology for patients undergoing surgical procedures, the objective of this work is to evaluate the cost-effectiveness and budget impact of the use of VHAs compared to the SOC in patients undergoing cardiac surgery in the Brazilian public health system.

\section{Methods}

\section{Cost-effectiveness analysis}

A decision tree model was built in TreeAge Pro 2009 to assess the cost-effectiveness relationship between VHAguided or SOC-guided transfusions. In this model, four categories of variables were used: the probability of occurrence of events, volumes of blood products transfused, costs of hospital treatment, treatment of adverse events and allogeneic blood transfusion and treatment outcomes. The perspective of the health system was adopted, as recommended by the Brazilian guidelines on pharmacoeconomic analysis (Brasil, 2009, 2014b). This assessment followed the principles of the CHEERS report (Husereau et al., 2013).

\section{Intervention}

Two devices are most commonly recommended to perform VHAs: (i) thromboelastography (TEG; Haemoscope Corporation, Niles, IL, USA), which was described in 1948 (Hartert, 1948; Luddington, 2005; and (ii) rotational thromboelastometry (ROTEM; Tem Innovations, GmbH, Munich, Germany), which is a modification of the thromboelastography method that emerged in the 1990s (Luddington, 2005;
Tem International $\mathrm{GmbH}$, 2016). The principle of these tests is the change in blood viscoelastic properties during clot formation. The firmer the clot, the greater the force opposing the rotation or vibration movement of the device (Simioni et al., 2008; Keene et al., 2013; Benes, et al., 2015; Görlinger et al., 2016; Tem International $\mathrm{GmbH}$, 2016; Zamper et al., 2017). The VHA used in this economic evaluation was the ROTEM".

\section{Comparator}

The VHAs were compared to the SOC, which is composed of standard laboratory tests and/or clinical decisions. The most common routine laboratory tests for coagulation control are prothrombin time (PT), activated partial thromboplastin time (aPTT), activated clotting time (ACT), platelet count (CP), and plasma fibrinogen concentration (CFP) (Whiting et al., 2015). As said before, the SOC procedures vary a lot between health services (Görlinger et al., 2013).

\section{Model}

The patients in the model enter one of the treatment groups and may or may not receive transfusions of RBC, FFP or platelets, or need to use fibrinogen or prothrombin complex. Patients may also undergo reoperation due to bleeding. After this, patients may live or die and, if they survive, they might have complications associated with the procedure, such as acute kidney injury, thromboembolic event or infection, or they might not suffer complications (Figure 1). The hypothetical cohort was constructed considering patients undergoing cardiac procedures with data from a previous meta-analysis conducted by the same research group (Supplementary Materials - Appendix 1). Each patient in the VHA group was considered to have been tested three times during the perioperative period and each test consisted of four trials: EXTEM, INTEM, FIBTEM and HEPTEM (Whiting et

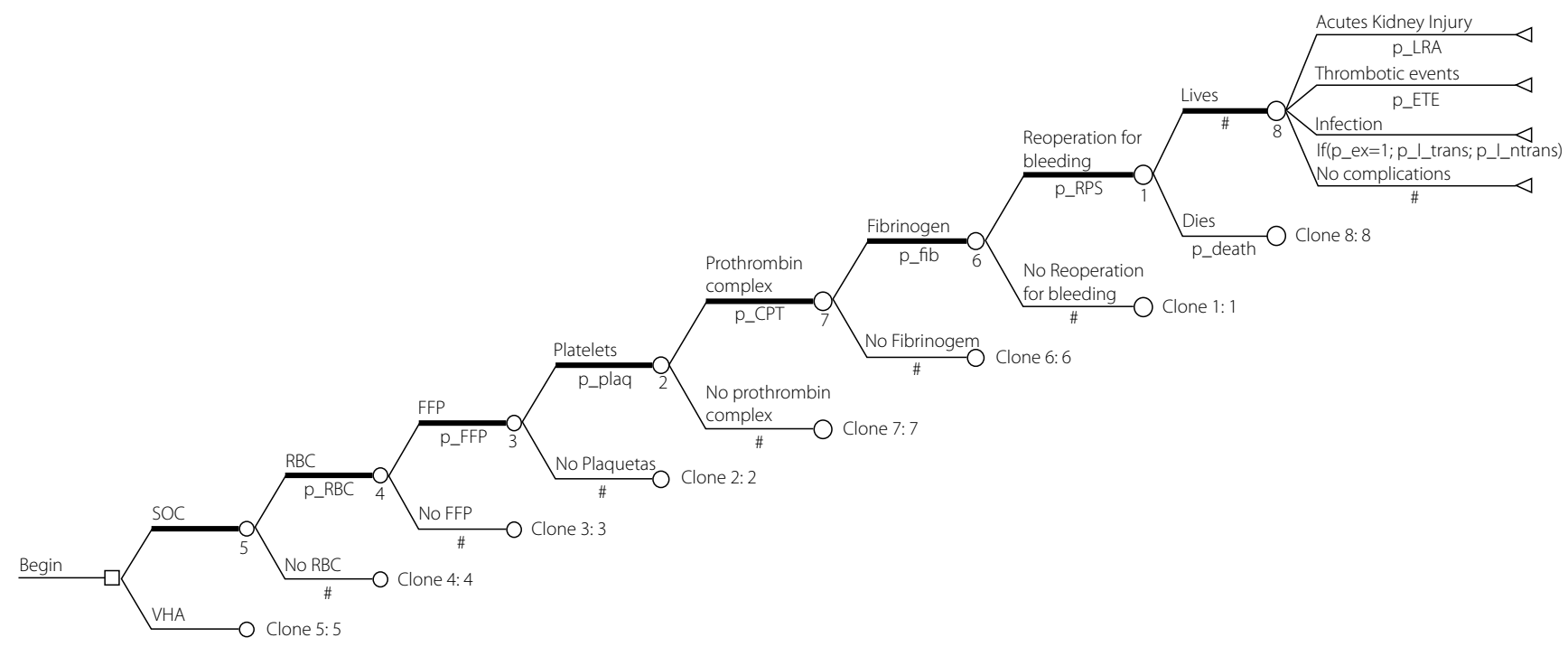

SOC: Standard-of-Care; VHA: viscoelastic haemostatic assay; RBC: red blood cell; FFP: fresh frozen plasma.

Figure 1. Schematic model. 
al., 2015) (Supplementary Materials - Appendix 2). In the SOC group, the tests performed were prothrombin time (PT), activated partial thromboplastin time (aPTT), activated clotting time (ACT), platelet count (PC), and plasma fibrinogen concentration (PFC) (Whiting et al., 2015) and it was considered that they were performed only once during the procedure.

\section{Probabilities}

Data on the probabilities of transfusion of RBC, FFP, platelets, fibrinogen and prothrombin complex, as well as the probabilities of death, reoperation from bleeding, acute kidney injury, and thromboembolic events, were taken from our meta-analysis. Data not available, such as the risk of infection, were derived from other studies published in the literature and duly explained and referenced (Supplementary Materials - Appendices 3). The risk of infection was estimated from a retrospective population-based study in the United Kingdom (Murphy et al., 2007). The data by Murphy et al. (2007) specifically address the risk of infections generated by the transfusion of RBCs. Patients who had infections, after being treated, were considered to have the same life expectancy as other patients who had no complications. These infections refer to patients who did not die as a result of the procedure within a short-term follow-up.

\section{Outcomes}

To calculate the clinical benefit of the technology, we used the population's life expectancy adjusted for complications. Thus, the results of the models were initially measured in terms of life-years gained (LYG). The life expectancy of patients with acute kidney injury was estimated based on the median survival observed in a study that evaluated the impact of the recovery of renal function on long-term mortality after coronary artery bypass grafting (Mehta et al., 2010). The median age of patients in the study was 65 years (IQR = 57-73). The median survival of patients who had and did not have acute kidney injury was extracted from the KaplanMeyer curve using the Engauge Digitizer ${ }^{\circ}$ 12.0. It was assumed that patients who had a nosocomial infection and did not die had the same life expectancy as individuals who did not have this event. The life expectancy of individuals who experienced thromboembolic events was estimated based on another specific study for individuals who experienced ischemic stroke (AVEi) (Brønnum-Hansen et al., 2001). In the study, about $72 \%$ of patients survived a stroke for more than 27 days, unlike the case of AKI in which few patients die at the beginning of the follow-up period (Mehta et al., 2010). In 10 years, the risk of death was about $76 \%$. As in-hospital and short-term mortality is considered in the model, the 10year survival time was used to estimate the life expectancy of patients who had a thromboembolic event and survived. The life expectancy data used is available in Supplementary Materials - Appendix 4.
Quality of life data from patients undergoing cardiac surgery are available in the literature (Oddershede et al., 2014; Heiskanen et al., 2016; Izawa et al., 2018). Izawa et al. (2018) examined age-related differences in health-related utility using the SF-6D scale in patients five months after cardiac surgery. They observed scores of $0.72 \pm 0.14$ in middle-aged patients and $0.71 \pm 0.10$ in elderly patients. These values are very close to the scores found by Oddershede et al. (2014) using the EQ-5D-3L. They found values of $0.72(S D=0.20 ; n=233)$ and $0.73(\mathrm{SD}=0.16 ; \mathrm{n}=149$ ) for patients in the estimation group and the validation group, respectively. Heiskanen et al. (2016) found utility values of 0.795 (0.765-0.826), in the baseline, and +0.053 (0.017-0.088) after 12 months. Given the proximity of the numbers, we decided to adopt a conservative approach and assume the value found by Oddershede et al. (2014) for being the largest sample among the three studies, which is roughly equivalent to the study by Izawa et al. (2018) who is the most recent. Disutility values were used in long-term adverse events. These disutilities were specifically applied to cases of thrombotic events and acute kidney injury since it was considered that individuals who had an infection and did not die had the same outcome as individuals who did not have complications. These data were taken from a WHO report on the disabilities used in the Global Burden of Disease (World Health Organization, 2018). In this way, outcomes were measured in quality-adjusted life-years (QALYS). The data on utility and disutility used in the models are available in Supplementary Materials - Appendix 5 and 6.

\section{Costs}

The costs with the equipment and its supplies were derived from a proposal made by the company that represents the product in Brazil (Biomig Brasil), varying by 20\% for more or less for the sensitivity analysis. A triangular distribution was used for the probabilistic sensitivity analysis, which only represents that there is a greater probability that the value will be close to that provided by the company. It is not an attempt to estimate a distribution for the variable. The costs were estimated from the perspective of the public health system, considering the company's proposal to work with the ROTEM ${ }^{\circ}$ Delta System 4-channel equipment in commodate with a minimum monthly purchase of $\$ 7,242.88$ PPPUSD in supplies. In commodate, there are no costs associated with the maintenance or depreciation of the equipment.

The cost of the cardiac procedure was estimated from a study of the literature for the public health system in Brazil (Titinger et al., 2015). In the study, the cost is calculated from the patient's risk at low (34\% of patients, 13,093.01 USD), moderate (39\% of patients, 16,829.63 USD) and high (27\% of patients, 20,876.06 USD). As data on mean and standard deviation for the procedures, in general, were not provided and the number of patients in each group is relatively close, instead of a gamma distribution, a triangular distribution 
was used with the most likely value equal to the cost of the procedure in a moderate patient and the minimum and maximum costs equal to a $20 \%$ variation in this cost, adjusted to the value in PPP-USD (2019). The cost of reoperation for bleeding was not found directly in the literature. However, a study carried out in the USA estimated that the incremental cost of reoperation for bleeding is between 63 and 179\% of the cost of the procedure (Gunnarsson et al., 2015). Thus, the same value of the cardiac procedure was used to parameterize a triangular distribution with a more likely value equal to the value of the procedure.

The costs of thromboembolic events were estimated based on the cost of treating a stroke, as this is the event most reported by the studies that measured thrombotic complications (Shore-Lesserson et al., 1995; Girdauskas et al., 2010; Paniagua et al., 2011; Weber et al., 2012). About $45 \%$ of the direct costs of AVEi in the first year are associated with hospital treatment (Bergman et al., 1995). Thus, the cost associated with the AVEi was estimated based on a study conducted in Brazil that evaluated the costs related to hospital treatment, considering the average and standard deviation data ([5,020 USD, SD = 3,065 USD (Safanelli et al., 2019). The cost of treating AKI was estimated based on data from a cost-effectiveness study carried out in Brazil for a 5-year time horizon (Ramirez et al., 2017).

No data were found on the treatment costs of cardiac surgery patients who had nosocomial infections in Brazil. Thus, the cost of nosocomial infections was estimated based on a study conducted in a philanthropic hospital in Belo Horizonte, Brazil. The study provided data on the median and interquartile range (Nangino et al., 2012). The costs associated with platelet concentrate, RBCs and FFP were estimated from the Hemominas Foundation's table of products and services [ordinance no. 251/2019 (Hemominas, 2019)] and varied by $20 \%$ for more and less in a triangular distribution, and the volumes found in the previous meta-analysis (Supplementary Materials - Appendix 7). The costs associated with fibrinogen and prothrombin complex were estimated from the average value reported in the Price Panel of the Ministry of Planning. Individuals who needed fibrinogen and prothrombin complex were considered to have used a unit. The costs used in the model are available in Supplementary Materials - Appendix 8 and 9. Data in BRL was converted to USD using the OECD Purchase Parity Power conversion rate (2.071 in 2019).

\section{Data analysis}

Most of the studies that provided data for this assessment were conducted in patients with age close to the median age of this population. In cases where the confidence interval of the analysis was not reported or there was no way to calculate it, a triangular distribution with a $20 \%$ variation in relation to the point estimate was considered, as previously stated.
The cost-effectiveness assessment was carried out using the expected value approach (Arrow \& Lind, 1970). The outcome was reported in QALYS. A univariate sensitivity analysis was performed on the number of tests performed and on the cost variables of RBCs, FFP, platelets, fibrinogen, prothrombin complex, routine laboratory tests, ROTEM ${ }^{\circ}$ tests and reoperation for bleeding. The result is reported in the form of a tornado diagram. The model variables were adjusted as distributions as instructed by Briggs et al. (2006), except when explicitly indicated, and a probabilistic sensitivity analysis (PSA) was conducted to assess the uncertainty in transition probabilities, costs and treatment outcomes through the simulation of 10,000 iterations. To determine the result of the study, various threshold values were considered (PichonRiviere et al., 2017; Santos et al., 2018, 2019). No discount rate was applied since the intervention was performed during a surgical procedure; i. e., it is a one-off event that is not chronic or repetitive. The costs of outcomes that are chronic were incorporated into the model from the perspective of total treatment cost at present value.

The VHAs were associated with a statistically significant reduction in mortality, risk of acute kidney injury, transfused red cell volume, risk of platelet transfusion, risk of FFP transfusion, and volume of FFP transfusion and a non-statistically significant advantage in terms of risk of reexploration for bleeding, risk of RBC transfusion, the volume of platelets transfused, use of fibrinogen, use of prothrombin complex, use of factor VIla, length of hospital stay or length of ICU stay (data from our own meta-analysis). Therefore, the higher the cost of adverse events is, the more the VHAs would be favored. Not to risk overestimating the cost of such adverse events, we conducted a secondary one-way sensitivity analysis dividing the costs of adverse events from 1 to 10 . These values were chosen for convenience. We believe that a 10 times reduction in the costs of adverse events is already high enough to leave no doubt about the results.

\section{Budget impact analysis}

According to the Ministry of Health's guideline, the cost of treating a disease consists of multiplying the population that would potentially benefit from the technology by the cost of the alternatives (Brasil, 2014a). The difference between these costs indicates the incremental budget impact. The budgetary impact analysis was carried out from the perspective of the budget holder, in this case, the public health system, like the cost-effectiveness analysis. As directed by the Ministry of Health, all direct costs related to technology for the payer were incorporated into the analysis (Brasil, 2014a). This includes differences in terms of the cost of adverse events and supplies used. The valuation was based on the company's minimum of $\$ 7,242.88$ USD minimum monthly purchase. In this way, the equipment can be supplied by commodate and there is no need to incorporate the equipment, maintenance 
and depreciation costs to the analyses. The analyses were made by scenario, to make the report as clear as possible. The VHAs market share was varied between 10 and 100\% with $10 \%$ jumps.

The decision tree used to evaluate the cost-effectiveness was adjusted to calculate the budget impact for the population of cardiac surgery patients with micro-simulation in a 5 -year time horizon. The values for the five years were calculated at present value, there was no adjustment for the discount rate. The assessment of the number of cardiac procedures performed in Brazil was calculated using Datasus, a government-maintained database. Data on the number of approved cardiovascular surgeries were obtained between 2008 and 2018 (Supplementary Materials - Appendix 10). The projection data for the years 2020 to 2024 was calculated using simple linear regression. The data fit was good $\left(R^{2}=\right.$ 0.945; Supplementary Materials - Appendix 11).

\section{Results}

\section{Cost-Effectiveness Analysis}

ROTEM ${ }^{\circ}$ was considered dominant over SOC in the base case scenario. It was associated with a lower cost $(\$ 25,440.07$ USD vs. \$26,421.44 USD) and higher effectiveness (8.262 QALYs vs. 7.829 QALYs; Table 1). The tornado diagram of the deterministic sensitivity analysis showed that the number of assays done during the perioperative period is the most influential variable to the ICER, followed by the cost of the procedure, cost of treatment of AKI, cost of reoperation for bleeding and the costs of the ROTEM ${ }^{\circ}$ assays. Nevertheless, none of these variables turned the ICER positive; i. e. in all evaluated scenarios in this sensitivity analysis, ROTEM ${ }^{\circ}$ is dominant to the SOC (Figure 2). The PSA showed strong robustness in the analysis (93.35\% of the iterations fell on the forth quadrant; higher effectiveness and lower cost). A small proportion of the iterations fell in the first quadrant (higher effectiveness and higher cost; 6.26\%). 5.95\% fell in the area below a threshold of 0.5 GDP per capita/QALY (4,460.40 in 2018; data from the World Bank) and $0.31 \%$ over this threshold (Figure 3).

As can be seen, a good part of the most influential variables to the ICER is associated with the costs of adverse events. The one-way sensitivity analysis considering the division of the costs of adverse events between 1 and 10 showed that, in group, they could turn the ICER positive when this divisor is higher than $\cong 2.55$ (Figure 4). Independently, even if the divisor is set to ten, the ICER would be equal to $\$ 1,083.21$ USD/QALY; that is, ROTEM ${ }^{\circ}$ would still be considered cost-effective when compared to any previously suggested threshold [Materiais Suplementares - Apêndice 12; (Santos et al., 2018, 2019)].

Table 1. Cost-effectiveness table of VHAs compared to SOC with outcomes measured in QALYS

\begin{tabular}{lcccccc}
\hline Technology & $\begin{array}{c}\text { Cost } \\
\text { (BRL) }\end{array}$ & $\begin{array}{c}\text { Incremental cost } \\
\text { (BRL) }\end{array}$ & $\begin{array}{c}\text { Effectiveness } \\
\text { (QALY) }\end{array}$ & $\begin{array}{c}\text { Incremental } \\
\text { Effectiveness } \\
\text { (QALY) }\end{array}$ & $\begin{array}{c}\text { CER } \\
\text { (BRL/QALY) }\end{array}$ & $\begin{array}{c}\text { ICER } \\
\text { (BRL/QALY) }\end{array}$ \\
\hline VHA & $\$ 25,440.07$ & & 8.262 & $3079 \$ / E$ & \\
\hline SOC & $\$ 26,421.44$ & $\$ 981.36$ & 7.829 & -0.433 & $3375 \$ / E$ & (Dominated) \\
\hline
\end{tabular}

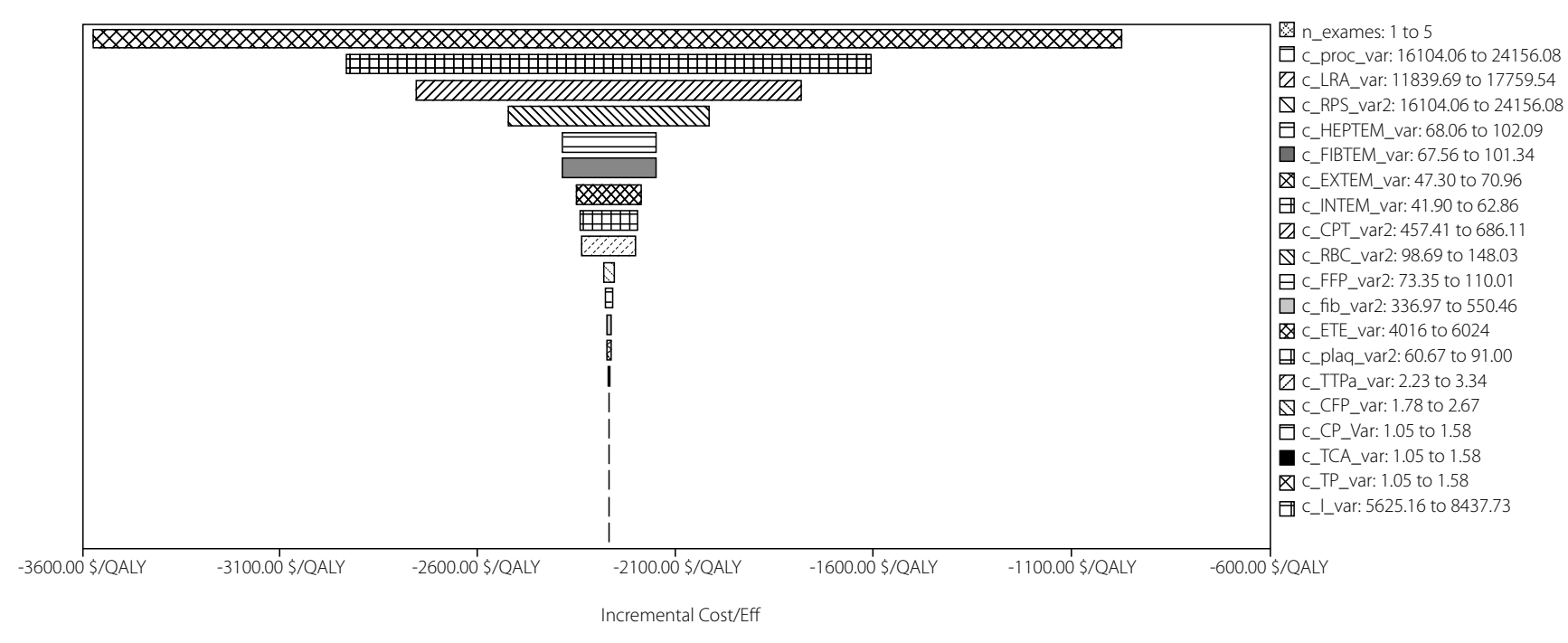

Figure 2. Tornado diagram of the cost-effectiveness ratio varying costs variables and number of exams order by impact on the ICER. 


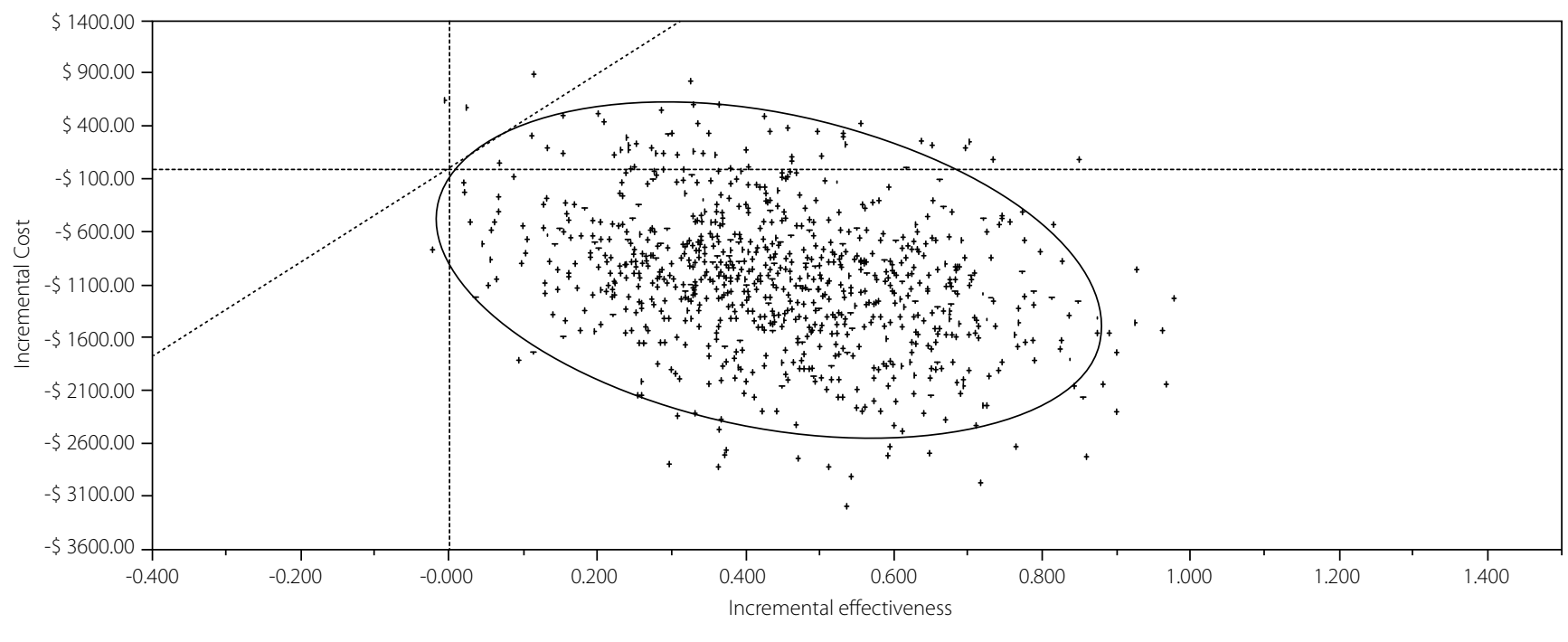

Figure 3. Incremental cost-effectiveness scatterplot between the VHA and SOC with outcomes measured in QALY and the threshold defined at zero.

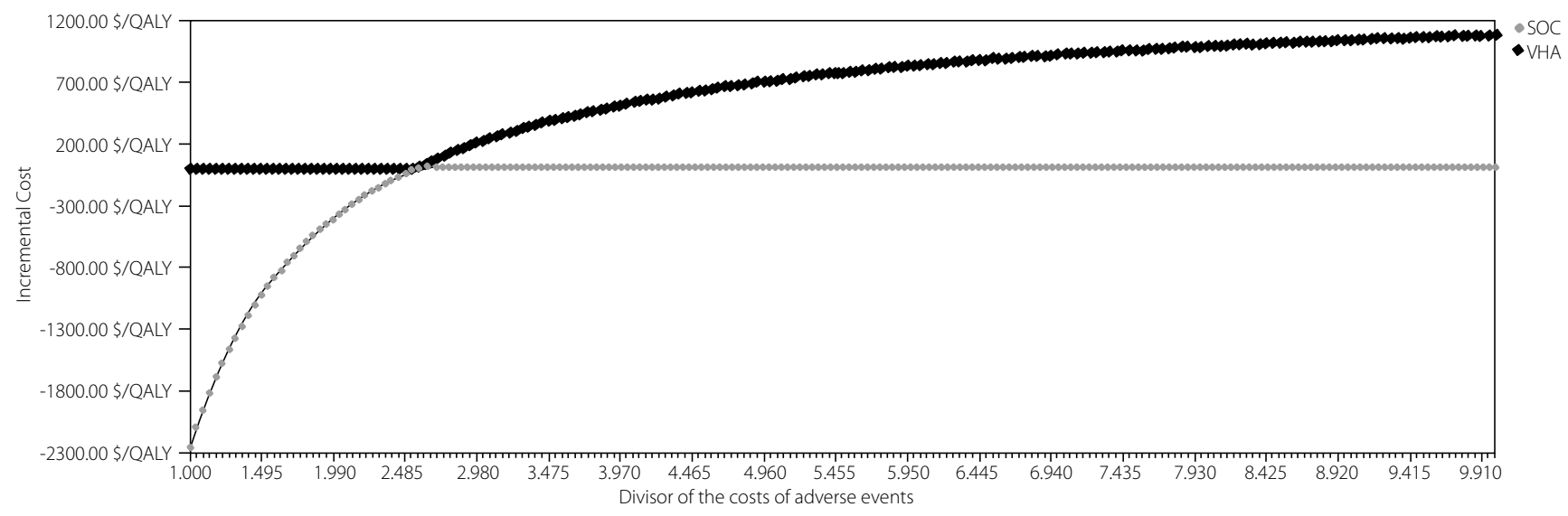

Figure 4. One-way sensitivity analysis considering that the costs of adverse event might not be totally imputed to the technologies and varying the divisor between 1 and 10.

\section{Budget impact analysis}

The results here are presented in two tables, considering the divisor of the cost of adverse events equal to 1 (base case scenario) and to 10 (worst case scenario). Table 2 shows the results of the base case scenario. As expected, the VHA would provide savings varying between $-\$ 90,237,868.62$ and $-\$ 902,378,686.20$ for a market share of $10 \%$ and $100 \%$, respectively, in five years. If the market share of the technology increased steadily absolute 10\% per year, the budget impact would be a saving of $-\$ 274,933,128.34$ in five years.

Table 3 shows the result of the worst-case scenario considered. In this scenario, the budget impact would be between $\$ 43,187,031.69$ and $\$ 431,870,316.85$ for a market share of $10 \%$ and $100 \%$, respectively, in five years. If the market share of the technology increased steadily absolute 10\% per year, the budget impact would be $\$ 131,624,071.34$ in five years.

\section{Discussion}

The efficiency analysis presented data favorable for the recommendation of the technology. The ICER showed dominance for ROTEM ${ }^{\circ}$ in the base case scenario and cost-effectiveness in the worst-case scenario compared to any previously suggested threshold. In the base case scenario, the VHA is very cost-saving (around -\$902 million USD). In the worst-case scenario, it has a maximum budget impact of about $\$ 432$ million USD. These scenarios with $100 \%$ market share are very unlikely, though. A more reasonable estimative for the base case scenario and the worst-case scenario are about $-\$ 275$ and $\$ 132$ million USD, respectively.

Health Technology Assessment agencies around the world have previously evaluated the cost-effectiveness of protocols based on VHAs in comparison to protocols based 
Table 2. Incremental budget impact of the VHA for cardiac procedures considering the total costs of adverse events

\begin{tabular}{|c|c|c|c|c|c|c|}
\hline $\begin{array}{c}\text { Market Share } \\
\text { ROTEM }\end{array}$ & 2020 & 2021 & 2022 & 2023 & 2024 & Total \\
\hline 0.1 & $-\$ 17,250,860.53$ & $-\$ 17,451,222.50$ & $-\$ 18,149,388.72$ & $-\$ 18,600,327.69$ & $-\$ 18,786,069.18$ & $-\$ 90,237,868.62$ \\
\hline 0.2 & $-\$ 34,501,721.06$ & $-\$ 34,902,445.01$ & $-\$ 36,298,777.43$ & $-\$ 37,200,655.38$ & $-\$ 37,572,138.35$ & $-\$ 180,475,737.24$ \\
\hline 0.3 & $-\$ 51,752,581.59$ & $-\$ 52,353,667.51$ & $-\$ 54,448,166.15$ & $-\$ 55,800,983.08$ & $-\$ 56,358,207.53$ & $-\$ 270,713,605.86$ \\
\hline 0.4 & $-\$ 69,003,442.12$ & $-\$ 69,804,890.02$ & $-\$ 72,597,554.87$ & $-\$ 74,401,310.77$ & $-\$ 75,144,276.70$ & $-\$ 360,951,474.48$ \\
\hline 0.5 & $-\$ 86,254,302.65$ & $-\$ 87,256,112.52$ & $-\$ 90,746,943.58$ & $-\$ 93,001,638.46$ & $-\$ 93,930,345.88$ & $-\$ 451,189,343.10$ \\
\hline 0.6 & $-\$ 103,505,163.19$ & $-\$ 104,707,335.03$ & $-\$ 108,896,332.30$ & $-\$ 111,601,966.15$ & $-\$ 112,716,415.06$ & $-\$ 541,427,211.72$ \\
\hline 0.7 & $-\$ 120,756,023.72$ & $-\$ 122,158,557.53$ & $-\$ 127,045,721.02$ & $-\$ 130,202,293.85$ & $-\$ 131,502,484.23$ & $-\$ 631,665,080.34$ \\
\hline 0.8 & $-\$ 138,006,884.25$ & $-\$ 139,609,780.04$ & $-\$ 145,195,109.73$ & $-\$ 148,802,621.54$ & $-\$ 150,288,553.41$ & $-\$ 721,902,948.96$ \\
\hline 0.9 & $-\$ 155,257,744.78$ & $-\$ 157,061,002.54$ & $-\$ 163,344,498.45$ & $-\$ 167,402,949.23$ & $-\$ 169,074,622.59$ & $-\$ 812,140,817.58$ \\
\hline 1 & $-\$ 172,508,605.31$ & $-\$ 174,512,225.05$ & $-\$ 181,493,887.16$ & $-\$ 186,003,276.92$ & $-\$ 187,860,691.76$ & $-\$ 902,378,686.20$ \\
\hline
\end{tabular}

Table 3. Incremental budget impact of the VHA for cardiac procedures considering the costs of adverse events divided by ten

\begin{tabular}{ccccccc}
\hline $\begin{array}{c}\text { Market Share } \\
\text { ROTEM }\end{array}$ & $\mathbf{2 0 2 0}$ & $\mathbf{2 0 2 1}$ & $\mathbf{2 0 2 2}$ & $\mathbf{2 0 2 3}$ & $\mathbf{2 0 2 4}$ & Total \\
\hline 0.1 & $\$ 8,235,621.49$ & $\$ 8,413,328.88$ & $\$ 8,634,957.27$ & $\$ 8,858,699.95$ & $\$ 9,044,424.09$ & $\$ 43,187,031.69$ \\
\hline 0.2 & $\$ 16,471,242.98$ & $\$ 16,826,657.76$ & $\$ 17,269,914.53$ & $\$ 17,717,399.91$ & $\$ 18,088,848.19$ & $\$ 86,374,063.37$ \\
\hline 0.3 & $\$ 24,706,864.47$ & $\$ 25,239,986.64$ & $\$ 25,904,871.80$ & $\$ 26,576,099.86$ & $\$ 27,133,272.28$ & $\$ 129,561,095.06$ \\
\hline 0.4 & $\$ 32,942,485.96$ & $\$ 33,653,315.52$ & $\$ 34,539,829.07$ & $\$ 35,434,799.81$ & $\$ 36,177,696.38$ & $\$ 172,748,126.74$ \\
\hline 0.5 & $\$ 41,178,107.45$ & $\$ 42,066,644.40$ & $\$ 43,174,786.33$ & $\$ 44,293,499.76$ & $\$ 45,222,120.47$ & $\$ 215,935,158.43$ \\
\hline 0.6 & $\$ 49,413,728.94$ & $\$ 50,479,973.28$ & $\$ 51,809,743.60$ & $\$ 53,152,199.72$ & $\$ 54,266,544.57$ & $\$ 259,122,190.11$ \\
\hline 0.7 & $\$ 57,649,350.43$ & $\$ 58,893,302.16$ & $\$ 60,444,700.87$ & $\$ 62,010,899.67$ & $\$ 63,310,968.66$ & $\$ 302,309,221.80$ \\
\hline 0.8 & $\$ 65,884,971.92$ & $\$ 67,306,631.04$ & $\$ 69,079,658.13$ & $\$ 70,869,599.62$ & $\$ 72,355,392.76$ & $\$ 345,496,253.48$ \\
\hline 0.9 & $\$ 74,120,593.41$ & $\$ 75,719,959.93$ & $\$ 77,714,615.40$ & $\$ 79,728,299.57$ & $\$ 81,399,816.85$ & $\$ 388,683,285.17$ \\
\hline 1 & $\$ 82,356,214.90$ & $\$ 84,133,288.81$ & $\$ 86,349,572.67$ & $\$ 88,586,999.53$ & $\$ 90,444,240.95$ & $\$ 431,870,316.85$ \\
\hline
\end{tabular}

on SOC (Craig et al., 2008; Whiting et al., 2015). Whiting et al. (2015) made an indirect assessment of the effect of reducing the volume of transfusion with clinical outcomes of patients based on data of strong associations presented in the literature. With that, they concluded the "probable" cost-effectiveness of the procedure. For the cardiac surgery model, savings of $£ 43$ GBP were observed with the use of ROTEM", $£ 79$ GBP with the use of $\mathrm{TEG}^{\circ}$, and $£ 132 \mathrm{GBP}$ with the use of the Sonoclot Analyzer (Whiting et al., 2015). The results found in Scotland are similar (Craig et al., 2008). The analysis of the scenarios suggested that VHAs remain cost-effective, except in two cases: when the number of tests per year is small or when VHAs are used as a complement to routine tests and not as substitutes (Craig et al., 2008; Whiting et al., 2015). These results are in consonance with ours, however, they were obtained from assumptions made based on intermediate outcomes, like the risk of transfusions. We used final outcomes and intermediate outcomes for our analysis.

It is very unlikely, given the results observed in our meta-analysis and other previously published studies, that this technology is not effective. A recent systematic review published by the Cochrane Collaboration reported that VHAs reduce mortality (7.4\% vs. 3.9\%; RR $=0.52 ; 95 \% \mathrm{Cl}=0.28-0.95 ;\left.\right|^{2}$ $=0 \% ; \mathrm{p}$-value $=0.033 ; 8$ studies; 717 participants; low level of evidence), the proportion of patients receiving $\mathrm{RBC}(\mathrm{RR}=0.86$; $95 \% \mathrm{Cl}=0.79-0.94 ; \mathrm{p}$-value $=0.001 ; \mathrm{I}^{2}=0 \% ; 10$ studies; 832 participants; low level of evidence), FFP (RR $=0.57 ; 95 \% \mathrm{Cl}=$ 0.33-0.96; $p$-value $=0.034 ; l^{2}=86 \% ; 8$ studies; 761 participants; low level of evidence), platelets ( $\mathrm{RR}=0.73 ; 95 \% \mathrm{Cl}=0.60-0.88$; $p$-value $=0.0012 ; I^{2}=0 \% ; 10$ studies; 832 participants; low level of evidence) and the risk of dialysis-dependent kidney failure $\left(\mathrm{RR}=0.46 ; 95 \% \mathrm{Cl}=0.28-0.76 ; \mathrm{p}\right.$-value $=0.0028 ; \mathrm{I}^{2}=0 \%$; three studies; 200 patients) (Wikkelsø et al., 2016; Wikkelsø et al., 2017). Other subsequent reviews, however, showed less favorable results for the technology (Fahrendorff et al., 2017; Serraino \& Murphy, 2017; Lodewyks et al., 2018).

Wikkelsø et al. (2016) included different populations to be able to demonstrate a significant benefit in terms of mortality with the use of VHAs. The problem with the demonstration of some of the beneficial effects of the VHAs seems to 
be the small samples included in the randomized controlled trials. Even clinically relevant improvements in final outcomes, such as mortality, could be difficult to demonstrate if the optimal information size is not achieved. Mortality is the most important final outcome included in all these meta-analyses. Another five systematic reviews assessed mortality outcomes. None of them reported statistically significant advantage with the use of VHA at a 5\% significance level, but most of them suffer from imprecision associated to small sample sizes and short follow-up periods (Deppe et al., 2016; Fahrendorff et al., 2017; Serraino \& Murphy, 2017; Lodewyks et al., 2018; Li et al., 2019). Some of them were able to demonstrate statistically significant results at a $10 \%$ significance level (Fahrendorff et al., 2017; Serraino \& Murphy, 2017). An important distinction here is that cardiac patients with high risk of bleeding or coagulopathies seem to be the most favored by the intervention in terms of short-term mortality [6.6\% vs. $20.6 \% ; \mathrm{RR}=0.33,95 \% \mathrm{Cl}=0.12-0.91, \mathrm{p}$-value $=0.03 ; \mathrm{I}^{2}=$ $0 \%$, p-value $=0.34$; two studies, 144 patients; random-effects model; (Santos et al., 2020)]. Another difficulty associated to the demonstration of relevant clinical results is the highly variable transfusion protocols used in different health services (Görlinger et al., 2013).

All previous meta-analysis found in the literature demonstrated significant advantages in terms of AKI (Deppe et al., 2016; Wikkelsø et al., 2016; Serraino \& Murphy, 2017; Wikkelsø et al., 2017). The advantage for VHAs in the risk of reoperation for bleeding was only showed by meta-analyses that included observational studies, which would be expected since their samples are much bigger (Bolliger \& Tanaka, 2013; Deppe et al., 2016; Li et al., 2019). What is odd is that the relative risks are much more favorable for the VHAs in these studies [0.42 to 0.67 vs. 0.75 to 0.82; (Bolliger \& Tanaka, 2013; Deppe et al., 2016; Wikkelsø et al., 2016; Serraino \& Murphy, 2017; Wikkelsø et al., 2017; Li et al., 2019)]. The results on the risk of transfusion are also much more favorable for the VHAs in meta-analysis that included observational studies (Bolliger \& Tanaka, 2013; Deppe et al., 2016; Wikkelsø et al., 2016; Serraino \& Murphy, 2017; Wikkelsø et al., 2017; Lodewyks et al., 2018; Li et al., 2019). There might be an overutilization of blood, blood products and blood components in the SOC group in observational studies. Since we might not be sure, we chose to use only data from randomized controlled trials in our meta-analysis. This "extra" advantage of the VHAs in meta-analyses that include observational studies is not seen for the mortality outcome (Deppe et al., 2016; Wikkelsø et al., 2016; Fahrendorff et al., 2017; Serraino \& Murphy, 2017; Wikkelsø et al., 2017; Lodewyks et al., 2018; Li et al., 2019).

All models are simplifications of reality and, therefore, decisions about the essential elements of an assessment must be made to ensure that a model is useful for decision making (Briggs et al., 2006). Complications resulting from the procedure or transfusions were not separated and were considered to have occurred within the hospitalization period, being attributed according to the result of the meta-analysis within each treatment arm. In incremental terms, it provides an assessment of how much has been gained in terms of clinical outcomes with the use of technology. The entire cost of treatment and loss of survival time associated with complications were considered within the arm of each technology. Considering the limitation of the minimum purchase of $\$ 7,242.88$ USD per month for supplies in commodate situations, the model is only valid if the technology is used in at least 8 patients per month, considering that the assays will be performed three times during the perioperative period. The cost data for adverse events were estimated from the medical literature. The LRA cost data were taken from the economic modeling study by Ramirez et al. (2017) from the perspective of the Supplementary Health System in Brazil over a five-year time horizon due to the lack of more precise data. Some cost data were estimated from triangular distributions due to a lack of data on mean and standard deviation to generate a normal or gamma distribution. The assumption adopted that the risk of infection is due to RBC only, which could be estimated from the study Murphy et al. (2007), may not be true. However, this assumption is quite conservative, given that the RR of platelet and plasma transfusion favor the intervention a lot. A patient could use more than one vial of prothrombin complex or fibrinogen. But, since we did not have the average consumption in the literature, we assumed one unit per patient. This is a conserved assumption given that it favors the SOC as well. The economic evaluation was carried out only considering ROTEM ${ }^{\circ}$. However, no important difference has been demonstrated between $\mathrm{TEG}^{\circ}$ and ROTEM ${ }^{\circ}$. The effect of both seems similar in relation to the outcomes (Wikkelsø et al., 2016; Fahrendorff et al., 2017; Serraino \& Murphy, 2017; Wikkelsø et al., 2017; Lodewyks et al., 2018; Li et al., 2019). The cost associated with TEG', though, is lower than the costs of ROTEM ${ }^{\circ}$. That way, considering the costs of ROTEM as VHA is also a conservative approach (Whiting et al., 2015).

\section{Conclusion}

A recent systematic review states that, currently, the benefits shown by VHAs are not sufficient to allow a recommendation for incorporation (Lodewyks et al., 2018). We respectfully disagree. Deppe et al. (2016) argue that the use of viscoelastic tests leads to a balanced transfusion regimen, decreases the amount of transfused products and can lead to a decrease in the rate of clinical complications. The authors also state and we agree that longer studies may be necessary to definitively demonstrate the effects of VHAs on mortality. Nevertheless, we would argue that (i) this is a technology that has been proven to be efficacious for final and intermediate outcomes by different meta-analyses (Deppe et al., 2016; Wikkels $\varnothing$ 
et al., 2016; Fahrendorff et al., 2017; Serraino \& Murphy, 2017; Wikkelsø et al., 2017; Lodewyks et al., 2018; Li et al., 2019), (ii) has been found cost-saving by different studies (Craig et al., 2008; Whiting et al., 2015), and (iii) has no adverse effects for patients. If this technology is not to be recommended, what is? Therefore, we conclude that the VHAs are cost-effective and should be recommended for the use in the perioperative period of cardiac surgeries, especially for patients with a high risk of hemorrhage or coagulation problems.

\section{Referências}

Andrade C. Propensity Score Matching in Nonrandomized Studies: A Concept Simply Explained Using Antidepressant Treatment During Pregnancy as an Example. J Clin Psychiatry. 2017;78(2):e162-5.

Aronson D, Dann EJ, Bonstein L, Blich M, Kapeliovich M, Beyar R, et al. Impact of Red Blood Cell Transfusion on Clinical Outcomes in Patients With Acute Myocardial Infarction. Am J Cardiol. 2008;102(2):115-9.

Arrow KJ, Lind RC. Uncertainty and the evaluation of public investment decisions. Am Econ Rev. 1970;60(3):364-78.

Benes J, Zatloukal J, Kletecka J. Viscoelastic Methods of Blood Clotting Assessment - A Multidisciplinary Review. Front Med (Lausanne). 2015;2:62.

Bergman L, van der Meulen JH, Limburg M, Habbema JD. Costs of Medical Care After First-Ever Stroke in the Netherlands. Stroke. 1995;26(10):1830-6.

Bhaskar B, Dulhunty J, Mullany DV, Fraser JF. Impact of Blood Product Transfusion on Short and Long-Term Survival After Cardiac Surgery: More Evidence. Ann Thorac Surg. 2012;94(2):460-7.

Bolliger D, Tanaka KA. Roles of thrombelastography and thromboelastometry for patient blood management in cardiac surgery. Transfus Med Rev. 2013;27(4):213-20.

Braile DM. Extracorporeal circulation. Rev Bras Cir Cardiovasc. 2010;25(4):III-V.

Brasil. Diretrizes Metodológicas: Análise de Impacto Orçamentário. Brasília: Ministério da Saúde; 2014a.

Brasil. Diretrizes Metodológicas: diretriz de avaliação econômica. Brasília: Ministério da Saúde; 2014b. Available from: http://bvsms.saude.gov. br/bvs/publicacoes/diretrizes_metodologicas_diretriz_avaliacao_ economica.pdf.

Brasil. Diretrizes Metodológicas: estudos de avaliação econômica de tecnologias em saúde. Brasília: Ministério da Saúde; 2009. Available from: https://www.ispor.org/peguidelines/source/economic-evaluationguidelines-in-brazil-final-version-2009.pdf.

Brasil. Ministério da Saúde. Datasus. 2019. Available from: http://www2. datasus.gov.br/DATASUS/index.php.

Brasil. Plano de ações estratégicas para o enfrentamento das doenças crônicas não transmissíveis (DCNT) no Brasil 2011-2022. Brasília-DF: Ministério da Saúde; 2011.

Briggs AH, Claxton K, Sculpher MJ. Decision modelling for health economic evaluation, Oxford handbooks in health economic evaluation. Oxford: Oxford University Press; 2006.

Brønnum-Hansen H, Davidsen M, Thorvaldsen P; Danish MONICA Study Group. Long-term survival and causes of death after stroke. Stroke. 2001;32(9):2131-6.

Costa F, et al. Hemotransfusão no pós-operatório de cirurgia. 2012.

Craig J, Aguiar-Ibanez R, Bhattacharya S, Downie S, Duffy S, Kohli H, et al. The clinical and cost effectiveness of thromboelastography/ thromboelastometry. Glasgow. 2008. Available from: http:// healthcareimprovementscotland.org/his/idoc.ashx?docid=4c42dd974305-4f33-ad82-29ce13a398d1\&version=-1
DANTPS/SVS/MS, D. de V. de D. e A. não T. e P. da S. Principais causas de morte - GBD/Brasil - Mortalidade - Painéis de Monitoramento - Centrais de Conteúdos - DASNT - SVS/MS; 2019.

Dellinger EP, Anaya DA. Infectious and immunologic consequences of blood transfusion. Crit Care. 2004;8 Suppl 2(Suppl 2):S18-23.

Deppe AC, Weber C, Zimmermann J, Kuhn EW, Slottosch I, Liakopoulos OJ, et al. Point-of-care thromboelastography/thromboelastometry-based coagulation management in cardiac surgery: a meta-analysis of 8332 patients. J Surg Res. 2016;203(2):424-33.

Engoren MC, Habib RH, Zacharias A, Schwann TA, Riordan CJ, Durham SJ. Effect of blood transfusion on long-term survival after cardiac operation. Ann Thorac Surg. 2002;74(4):1180-6.

Fahrendorff M, Oliveri RS, Johansson PI. The use of viscoelastic haemostatic assays in goal-directing treatment with allogeneic blood products - A systematic review and meta-analysis. Scand J Trauma Resusc Emerg Med. 2017;25(1):39.

Girdauskas E, Kempfert J, Kuntze T, Borger MA, Enders J, Fassl J, et al. Thromboelastometrically guided transfusion protocol during aortic surgery with circulatory arrest: a prospective, randomized trial. J Thorac Cardiovasc Surg. 2010;140(5):1117-24.e2.

Glance LG, Dick AW, Mukamel DB, Fleming FJ, Zollo RA, Wissler R, et al. Association between Intraoperative Blood Transfusion and Mortality and Morbidity in Patients Undergoing Noncardiac Surgery. Anesthesiology. 2011;114(2):283-92.

Görlinger K, Dirkmann D, Hanke AA. Rotational Thromboelastometry (ROTEM ${ }^{\circledR}$ ). In: Gonzalez E, Moore HB, Moore EE. Trauma Induced Coagulopathy. Cham: Springer International Publishing; 2016. p. 267-98.

Görlinger K, Shore-Lesserson L, Dirkmann D, Hanke AA, Rahe-Meyer N, Tanaka KA. Management of Hemorrhage in Cardiothoracic Surgery. J Cardiothorac Vasc Anesth. 2013;27(4 Suppl):S20-34.

Gunnarsson C, Lim S, David G, Riebman J, Martin L, Kocharian R. The Incremental cost of reoperations for bleeding events in cardiac and vascular reconstructive surgery. Value Health. 2015;18(3):A140.

Hartert H. Blutgerinnungsstudien mit der Thrombelastographie, einem neuen Untersuchungsverfahren. Klinische Wochenschrift. 1948;26(3738):577-83.

Heiskanen J, Tolppanen AM, Roine RP, Hartikainen J, Hippeläinen M, Miettinen $\mathrm{H}$, et al. Comparison of EQ-5D and 15D instruments for assessing the health-related quality of life in cardiac surgery patients. Eur Heart J Qual Care Clin Outcomes. 2016;2(3):193-200.

Hemominas. Tabela de produtos e serviços hemoterápicos. Portaria PRE/ Hemominas no 251/2019, de 22 de julho de 2019. Available from: http:// www.hemominas.mg.gov.br/transparencia\#dados-abertos. Accessed on: Nov 21, 2019.

Horvath KA, Acker MA, Chang H, Bagiella E, Smith PK, Iribarne A, et al. Blood transfusion and infection after cardiac surgery. Ann Thorac Surg. 2013;95(6):2194-201.

Husereau D, Drummond M, Petrou S, Carswell C, Moher D, Greenberg D, et al. Consolidated Health Economic Evaluation Reporting Standards (CHEERS) statement. BMJ. 2013;346:f1049.

Izawa KP, Kasahara Y, Hiraki K, Hirano Y, Oka K, Watanabe S. Relationship between daytime sleepiness and health utility in patients after cardiac surgery: A preliminary study. Int J Environ Res Public Health. 2018;15(12):2716.

Keene DD, Nordmann GR, Woolley T. Rotational thromboelastometry-guided trauma resuscitation. Curr Opin Crit Care. 2013;19(6):605-12.

Li C, Zhao Q, Yang K, Jiang L, Yu J. Thromboelastography or rotational thromboelastometry for bleeding management in adults undergoing cardiac surgery: a systematic review with meta-analysis and trial sequential analysis. J Thorac Dis. 2019;11(4):1170-81. 
Lier H, Vorweg M, Hanke A, Görlinger K. Thromboelastometry guided therapy of severe bleeding. Essener Runde algorithm. Hamostaseologie. 2013;33(1):51-61.

Lodewyks C, Heinrichs J, Grocott HP, Karkouti K, Romund G, Arora RC, et al. Point-of-care viscoelastic hemostatic testing in cardiac surgery patients: a systematic review and meta-analysis. Can J Anaesth. 2018;65(12):1333-47.

Luddington RJ. Thrombelastography/thromboelastometry. Clin Lab Haematol. 2005;27(2):81-90.

Marik PE, Corwin HL. Efficacy of red blood cell transfusion in the critically ill: A systematic review of the literature. Crit Care Med. 2008;36(9):2667-74.

Massa KHC, Duarte YAO, Chiavegatto Filho ADP. Análise da prevalência de doenças cardiovasculares e fatores associados em idosos, 2000-2010. Ciênc Saúde Coletiva. 2019;24(1):105-14.

Mehta RH, Honeycutt E, Patel UD, Lopes RD, Shaw LK, Glower DD, et al. Impact of recovery of renal function on long-term mortality after coronary artery bypass grafting. Am J Cardiol. 2010;106(12):1728-34.

Miana LA, Atik FA, Moreira LFP, Hueb AC, Jatene FB, Auler Junior JO, et al. Fatores de risco de sangramento no pós-operatório de cirurgia cardíaca em pacientes adultos. Rev Bras Cir Cardiovasc. 2004;19(3):280-6.

Murphy GJ, Pike K, Rogers CA, Wordsworth S, Stokes EA, Angelini GD, et al. Liberal or restrictive transfusion after cardiac surgery. N Engl J Med. 2015;372(11):997-1008.

Murphy GJ, Reeves BC, Rogers CA, Rizvi SI, Culliford L, Angelini GD. Increased mortality, postoperative morbidity, and cost after red blood cell transfusion in patients having cardiac surgery. Circulation. 2007;116(22):2544-52.

Nangino GO, Oliveira CD, Correia PC, Machado NM, Dias ATB. Impacto financeiro das infecções nosocomiais em unidades de terapia intensiva em hospital filantrópico de Minas Gerais. Rev Bras Ter Intensiva. 2012;24(4):357-61.

Oddershede L, Andreasen JJ, Ehlers L. Estimation of utility values from visual analog scale measures of health in patients undergoing cardiac surgery. Clinicoecon Outcomes Res. 2014;6:21-7.

Paniagua P, Koller T, Requena T, Gil JM, Campos JM, Galan J. Randomized controled trial to evaluate postoperative coagulation management with bed-side trombelastometry (Rotem) compared with a transfusion protocol based on laboratory meausurments in bleeding patients after cardiac surgery: preliminary data. Eur J Anaesthesiol. 2011;28:94.

Pichon-Riviere A, Augustovski F, Marti SG. The efficiency path to universal health coverage: derivation of cost-effectiveness thresholds based on health expenditures and life expectancy. Updated country-level estimates for 194 countries [Internet]. 6th ISPOR Latin America. Sao Paulo: ISPOR; 2017. Available from: https://www.ispor.org/ conferences/2017SaoPaulo/Conference_Research_Abstracts.pdf

Prince MJ, Wu F, Guo Y, Gutierrez Robledo LM, O'Donnell M, Sullivan R, et al. The burden of disease in older people and implications for health policy and practice. Lancet. 2015;385(9967):549-62.

Ramirez MG, Costa MC, Costa MDM. Análise de custo-efetividade da terapia renal substitutiva contínua versus intermitente para pacientes graves com lesão renal aguda, na perspectiva do Sistema Suplementar de Saúde brasileiro. J Bras Econ Saúde. 2017;9(2):152-8.

Safanelli J, Vieira LGDR, Araujo T, Manchope LFS, Kuhlhoff MHR, Nagel V, et al. The cost of stroke in a public hospital in Brazil: a one-year prospective study. Arq Neuropsiquiatr. 2019;77(6):404-11.

Santos AA, Sousa AG, Piotto RF, Pedroso JC. Mortality risk is dose-dependent on the number of packed red blood cell transfused after coronary artery bypass graft. Rev Bras Cir Cardiovasc. 2013;28(4):509-17.

Santos AS, Guerra-Junior AA, Godman B, Morton A, Ruas CM. CostEffectiveness Thresholds: methods for setting and examples from around the world. Expert Rev Pharmacoecon Outcomes Res. 2018;18(3):277-88.
Santos AS, Guerra-Junior AA, Noronha KVMS, Andrade MV, Ruas CM. The Price of Substitute Technologies. Value Health Reg Issues. 2019;20:154-8.

Santos AS, Noronha KVMS, Andrade MV. Routine use of viscoelastic blood tests for diagnosis and treatment of coagulopathic bleeding in cardiac surgery. Response to Br J Anaesth 2017; 118: 823-33. Br J Anaesth. 2020;124(1):e1-e2.

Santos ATL, Splettstosser JC, Warpechowski P, Gaidzinski MMP. Antifibrinolíticos e cirurgia cardíaca com circulação extracorpórea. Rev Bras Anestesiol. 2007;57(5):549-64.

Santos MAS, Oliveira MM, Andrade SSCA, Nunes ML, Malta DC, Moura L. Tendências da morbidade hospitalar por doenças crônicas não transmissíveis no Brasil, 2002 a 2012. Epidemiol Serv Saúde. 2015;24(3):398-89.

Serraino GF, Murphy GJ. Routine use of viscoelastic blood tests for diagnosis and treatment of coagulopathic bleeding in cardiac surgery: updated systematic review and meta-analysis. Br J Anaesth. 2017;118(6):823-33.

Shore-Lesserson L, Reich DL, DePerio M, Silvay G. Autologous platelet-rich plasmapheresis: risk versus benefit in repeat cardiac operations. Anesth Analg. 1995;81(2):229-35.

Silva FCR, Totó YR, Lima LR de, Brandão GMON. Hemotransfusão no pósoperatório de cirurgia cardíaca. [Internet]. Anapolis, GO; 2012. Available from: http://www.unievangelica.edu.br/anais/enfermagem/14_semana/ trabalhos/06.pdf

Simioni P, Spiezia L, Radu C, Bertini D. New rotation thromboelastography (ROTEM) in thrombotic and haemorrhagic disorders: lights and shadows. Hematol Meet Rep. 2008;2(1).

Siqueira ASE, Siqueira-Filho AG, Land MGP. Análise do impacto econômico das doenças cardiovasculares nos últimos cinco anos no brasil. Arq Bras Cardiol. 2017;109(1):39-46.

Souza DK, Peixoto SV. Estudo descritivo da evolução dos gastos com internações hospitalares por condições sensíveis à atenção primária no Brasil, 2000-2013. Epidemiol Serv Saúde. 2017;26(2):285-94.

Souza MHL, Elias DO. Fundamentos da circulação extracorpórea. 2a ed. Rio de Janeiro: Centro Editorial Alfa Rio; 2006

Stevens B, Pezzullo L, Verdian L, Tomlinson J, George A, Bacal F. The economic burden of heart conditions in Brazil. Arq Bras Cardiol. 2018;111(1):29-36.

Tem International $\mathrm{GmbH}$. Targeted therapy stops the bleeding. ROTEM ${ }^{\bullet}$ delta ROTEM ${ }^{\oplus}$ platelet. 2016.

Theme Filha MM, Souza Junior PRB, Damacena GN, Szwarcwald CL. Prevalência de doenças crônicas não transmissiveis e associação com autoavaliação de saúde: Pesquisa nacional de saúde, 2013. Rev Bras Epidemiol. 2015;18:83-96.

Titinger DP, Lisboa LA, Matrangolo BL, Dallan LR, Dallan LA, Trindade EM, et al. Cardiac surgery costs according to the preoperative risk in the Brazilian public health system. Arq Bras Cardiol. 2015;105(2):130-8.

Wang SC, Shieh JF, Chang KY, Chu YC, Liu CS, Loong CC, et al. Thromboelastography-guided transfusion decreases intraoperative blood transfusion during orthotopic liver transplantation: randomized clinical trial. Transplant Proc. 2010;42(7):2590-3.

Weber CF, Görlinger K, Meininger D, Herrmann E, Bingold T, Moritz A, et al. Point-of-care testing: a prospective, randomized clinical trial of efficacy in coagulopathic cardiac surgery patients. Anesthesiology. 2012;117(3):531-47.

Whiting P, Al M, Westwood M, Ramos IC, Ryder S, Armstrong N, et al. Viscoelastic point-of-care testing to assist with the diagnosis, management and monitoring of haemostasis: a systematic review and cost-effectiveness analysis. Health Technol Assess. 2015;19(58):1-228, v-vi. 
Whitlock R, Crowther MA, Ng HJ. Bleeding in cardiac surgery: Its prevention and treatment - An evidence-based review. Crit Care Clin. 2005;21(3):589-610.

Wikkelsø A, Wetterslev J, Møller AM, Afshari A. Thromboelastography (TEG) or rotational thromboelastometry (ROTEM) to monitor haemostatic treatment in bleeding patients: a systematic review with meta-analysis and trial sequential analysis. Anaesthesia. 2017;72(4):519-31.

Wikkelsø A, Wetterslev J, Møller AM, Afshari A. Thromboelastography (TEG) or thromboelastometry (ROTEM) to monitor haemostatic treatment versus usual care in adults or children with bleeding. Cochrane Database Syst Rev. 2016;2016(8):CD007871.
World Health Organization. WHO methods and data sources for global burden of disease estimates 2000-2016. Geneva. 2018. Available from: https://www.who.int/healthinfo/global_burden_disease/GlobalDALY_ method_2000_2016.pdf.

Zamper RPC, Amorim TC, Costa LGVD, Takaoka F, Serpa A Neto. The role of thromboelastometry in the assessment and treatment of coagulopathy in liver transplant patients. Einstein (Sao Paulo). 2017;15(2):243-6.

\section{APPENDICES}

\section{Characteristics of participants in the primary studies included}

\begin{tabular}{|c|c|c|c|c|c|c|c|c|c|c|c|}
\hline Randomized Controlled Trial & 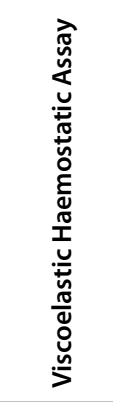 & $\mathbf{z}$ & 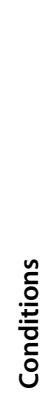 & $\begin{array}{l}\text { 촌 } \\
\stackrel{5}{0}\end{array}$ & 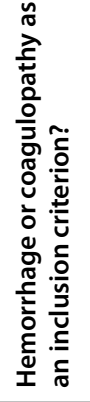 & 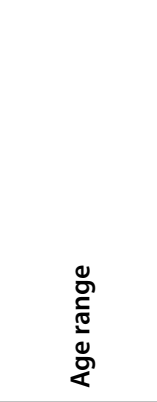 & 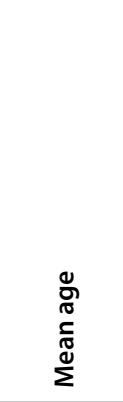 & 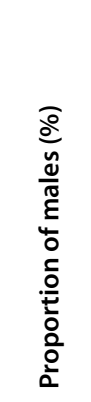 & $\begin{array}{l}\sum_{\infty} \\
\Sigma \\
\Sigma \\
\sum\end{array}$ & 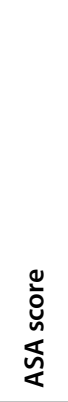 & 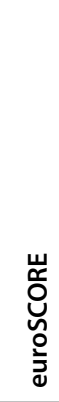 \\
\hline Ak et al., 2009 & TEG & 224 & C & Turkey & No & NA & 64.5 & 86.5 & NA & NA & 2.9 \\
\hline Avidan et al., 2004 & TEG & 210 & C & United Kingdom & No & NA & 64 & 78 & 27.55 & NA & NA \\
\hline Cao et al., $2015^{1}$ & TEG & 60 & $\mathrm{O}$ & China & Yes & NA & NA & NA & NA & NA & NA \\
\hline Cui et al., 2010 & TEG & 31 & C & China & No & NA & 38.36 & NA & NA & NA & NA \\
\hline De Pietri et al., 2016 & TEG & 60 & $H$ & Italy & Yes & 18 a 80 & 58.2 & 63.3 & NA & NA & NA \\
\hline Girdauskas et al., 2010 & ROTEM & 56 & C & Germany & No & $>18$ & 61.64 & 57.55 & 27.26 & NA & NA \\
\hline Gonzalez et al., 2015 & TEG & 111 & $\mathrm{~T}$ & USA & Yes & $>18$ & 39.51 & 70.21 & 25.70 & NA & NA \\
\hline Karkouti et al., 2016 & ROTEM & 7402 & C & Canada & No & NA & 67 & 74.96 & NA & NA & NA \\
\hline Kempfert et al., $2011^{1}$ & ROTEM & 104 & C & Germany & Yes & NA & 67.2 & NA & NA & NA & 7 \\
\hline Khalaf Adeli et al., $2017^{1}$ & ROTEM & 80 & C & Iran & No & NA & NA & NA & NA & NA & NA \\
\hline Kultufan Turan et al., 2006 & ROTEG & 40 & C & Turkey & No & NA & NA & NA & NA & NA & NA \\
\hline Lehmann et al., 2019 & ROTEM & 26 & C & Germany & Yes & $\geq 18$ & 70.75 & 67 & NA & NA & 5.5 \\
\hline Nakayama et al., 2015 & ROTEM & 100 & C & Japan & No & $\begin{array}{l}3 \text { to } 28 \\
\text { months }\end{array}$ & $\begin{array}{c}11.5 \\
\text { months }\end{array}$ & 64 & 16.3 & NA & NA \\
\hline Nuttall et al., 2001 & TEG & 92 & C & USA & Yes & $\geq 30$ & 68.5 & 72.6 & 27.4 & NA & NA \\
\hline Paniagua et al., $2011^{1}$ & ROTEM & 22 & C & Spain & Yes & $\geq 18$ & NA & NA & NA & NA & NA \\
\hline Royston \& Von Kier, 2001 & TEG & 60 & C & United Kingdom & No & 21 A 83 & NA & NA & NA & NA & NA \\
\hline Schaden et al., 2012 & ROTEM & 30 & Q & Austria & No & 17 A 87 & 52.75 & 60 & 26.8 & NA & NA \\
\hline Shore-Lesserson et al., 1999 & TEG & 105 & C & USA & No & 49.5 A 81.6 & 52.75 & 57.69 & NA & NA & NA \\
\hline Wang et al., 2010 & TEG & 28 & $\mathrm{H}$ & Taiwan & No & 38.8 A 63.8 & 65.8 & 64.28 & 24.2 & NA & NA \\
\hline Weber et al., 2012 & ROTEM & 100 & C & Germany & Yes & $\geq 18$ & 71 & 62 & 26 & 3 & 6.7 \\
\hline Westbrook et al., 2009 & TEG & 60 & C & Australia & No & NA & 63.65 & 70.25 & NA & NA & NA \\
\hline
\end{tabular}

$\mathrm{C}$ : cardiac procedures; $\mathrm{H}$ : hepatic procedures; Q: burned victims procedures; O: orthopedic procedures; Ob: obstetric procedures; T: trauma patient procedures. ${ }^{1}$ Full text unavailable. 
2. Cost of supplies to perform ROTEM tests on cardiac patients considering that the equipment will be provided by commodatum

\begin{tabular}{llcccc}
\hline Tests & Reagents needed per test & $\begin{array}{c}\text { Number of } \\
\text { tests }\end{array}$ & $\begin{array}{c}\text { Unit cost } \\
\text { (USD) }\end{array}$ & $\begin{array}{c}\text { Total Cost } \\
\text { (USD) }\end{array}$ & Reference \\
\hline INTEM & INTEM, STARTEM, cup/pin e 2 pipette tips & 3 & 52.38 & 157.14 & $\begin{array}{c}\text { Company proposal and } \\
\text { (Whiting et al., 2015) }\end{array}$ \\
\hline EXTEM & EXTEM, STARTEM, cup/pin e 2 pipette tips & 3 & 59.130 & 177.39 & 253.34 \\
\hline FIBTEM & FIBTEM, EXTEM, cup/pin e 3 pipette tips & 3 & 84.45 & 0 \\
\hline APTEM & APTEM, EXTEM, cup/pin e 3 pipette tips & 0 & 85.074 & 249.18 \\
\hline HEPTEM & HEPTEM, INTEM, cup/pin e 3 pipette tips & 3 & 83.06 & \\
\hline Total & & & & $\mathbf{8 3 7 . 0 5}$ \\
\hline
\end{tabular}

\section{Distribution of transition probabilities}

\begin{tabular}{|c|c|c|c|c|c|}
\hline Name & Description & Distribution & r & $\mathbf{n}$ & References \\
\hline P_death_VHA & Probability of death with the use of VHAs. & Beta & 12 & 350 & Own meta-analysis \\
\hline P_death_soc & Probability of death with the use of SOC & Beta & 23 & 339 & Own meta-analysis \\
\hline P_RBC_VHA & Probability of transfusion of RBCs with the use of VHAs. & Beta & 2025 & 4306 & Own meta-analysis \\
\hline P_RBC_soC & Probability of transfusion of RBCs with the use of SOC. & Beta & 1887 & 4003 & Own meta-analysis \\
\hline P_FFP_VHA & Probability of transfusion of FFP with the use of VHAs. & Beta & 1024 & 4269 & Own meta-analysis \\
\hline P_FFP_SOC & Probability of transfusion of FFP with the use of SOC. & Beta & 906 & 3969 & Own meta-analysis \\
\hline P_plaq_VHA & Probability of transfusion of platelets with the use of VHAs. & Beta & 1036 & 4306 & Own meta-analysis \\
\hline P_plaq_soc & Probability of transfusion of platelets with the use of SOC. & Beta & 1090 & 4003 & Own meta-analysis \\
\hline P_LRA_VHA & Probability of acute kidney injury with the use of VHAs. & Beta & 24 & 228 & Own meta-analysis \\
\hline P_LRA_SOC & Probability of acute kidney injury with the use of SOC. & Beta & 39 & 221 & Own meta-analysis \\
\hline P_ETE_VHA & Probability of thrombotic events with the use of VHAs. & Beta & 5 & 156 & Own meta-analysis \\
\hline P_ETE_soc & Probability of thrombotic events with the use of SOC. & Beta & 5 & 149 & Own meta-analysis \\
\hline P_RPS_VHA & Probability of reoperation for bleeding with the use of VHAs. & Beta & 36 & 444 & Own meta-analysis \\
\hline P_RPS_SOC & Probability of reoperation for bleeding with the use of SOC. & Beta & 48 & 443 & Own meta-analysis \\
\hline P_I_trans & Probability of infections in patients that received RBCs. & Beta & 596 & 4842 & (Murphy et al., 2007) \\
\hline P_I_ntrans & Probability of infections in patients that did not receive RBCs. & Beta & 141 & 3674 & (Murphy et al., 2007) \\
\hline P_CPT_VHA & Probability of use of prothrombin complex with the use of VHAs. & Beta & 26 & 91 & Own meta-analysis \\
\hline P_CPT_sOC & Probability of use of prothrombin complex with the use of SOC. & Beta & 52 & 95 & Own meta-analysis \\
\hline P_fib_VHA & Probability of fibrinogen use in patients who used VHAs. & Beta & 53 & 77 & Own meta-analysis \\
\hline P_fib_soc & Probability of fibrinogen use in patients who used SOC. & Beta & 56 & 79 & Own meta-analysis \\
\hline
\end{tabular}

\section{Distributions of patients' life expectancy data depending on complications}

\begin{tabular}{llccccc}
\hline Variable & Description & Distribution & Min & $\begin{array}{c}\text { Most } \\
\text { likely }\end{array}$ & Max & References \\
\hline O_LRA & Life expectancy of patients with acute kidney injury. & Triangular & 8.7 & 10.9 & 13.1 & (Mehta et al., 2010) \\
O_ETE & Patients'life expectancy after a thromboembolic event. & Triangular & 8 & 10 & 12 & (Brønnum-Hansen et al., 2001) \\
O_I & Patients'life expectancy after nosocomial infection. & Triangular & 9.8 & 12.3 & 14.8 & (Mehta et al., 2010) \\
O_SC & Life expectancy of patients without complications. & Triangular & 9.8 & 12.3 & 14.8 & (Mehta et al., 2010) \\
\hline
\end{tabular}

\section{Distribution of quality of life of patients who have undergone cardiac surgery}

\begin{tabular}{llcccc}
\hline Variable & Description & Distribution & $\overline{\mathbf{x}}$ & SE & References \\
\hline O_qol & Quality of life of patients after uncomplicated cardiac surgery & Normal & 0.72 & 0.01310244 & (Oddershede et al., 2014) \\
\hline
\end{tabular}


6. Disutility variables used in the model

\begin{tabular}{llcc}
\hline Variable & Description & $\overline{\mathbf{x}}$ & References \\
\hline O_qol_LRA & Disutility associated with acute kidney injury. & 0.104 & $\begin{array}{c}\text { WHO methods and data sources for global burden of } \\
\text { disease estimates 2000-2016 in Chronic kidney disease } \\
\text { (stage IV) }\end{array}$ \\
\hline O_qol_ETE & Disutility associated with thromboembolic events. & 0.070 & $\begin{array}{c}\text { WHO methods and data sources for global burden } \\
\text { of disease estimates 2000-2016 in Stroke: long-term } \\
\text { consequences, moderate }\end{array}$ \\
\hline O_qol_I & Disutility associated with infections. & 0 & Oddershede et al. (2014)
\end{tabular}

7. Distribution of transfused volume variables

\begin{tabular}{llcccc}
\hline Variable & Description & Distribution & $\overline{\mathbf{x}}$ & SE & References \\
\hline V_RBC_VHA & Volume of RBCs transfused in patients using VHAs. & Normal & 1.416 & 0.2676 & (Shore-Lesserson et al., 1999) \\
\hline V_RBC_sOC & Volume of RBCs transfused in patients using SOC. & Normal & 1.9 & 0.3289 & (Shore-Lesserson et al., 1999) \\
\hline V_FFP_VHA & Volume of FFP transfused in patients using VHAs. & Normal & 0.133 & 0.0723 & (Shore-Lesserson et al., 1999) \\
\hline V_FFP_sOC & Volume of FFP transfused in patients using SOC. & Normal & 0.804 & 0.2378 & (Shore-Lesserson et al., 1999) \\
\hline v_plaq_VHA & Volume of platelets transfused in patients using VHAs. & Normal & 0.1 & 0.0379 & (Shore-Lesserson et al., 1999) \\
\hline V_plaq_SOC & Volume of platelets transfused in patients using SOC. & Normal & 0.244 & 0.0653 & (Shore-Lesserson et al., 1999) \\
\hline
\end{tabular}

8. Distribution of the cost analysis variables of the exams and adverse events

\begin{tabular}{|c|c|c|c|c|c|c|}
\hline Variable & Description & Distribution & Min & $\begin{array}{l}\text { Most } \\
\text { likely }\end{array}$ & Max & References \\
\hline C_INTEM & Unit cost of INTEM ${ }^{\circ}$ & Triangular & 41.90 & 52.38 & 62.86 & $\begin{array}{c}\text { Biomig Materiais } \\
\text { Médico-Hospitalares Ltda. }\end{array}$ \\
\hline C_EXTEM & Unit cost of EXTEM & Triangular & 47.30 & 59.13 & 70.96 & $\begin{array}{l}\text { Biomig Materiais } \\
\text { Médico-Hospitalares Ltda. }\end{array}$ \\
\hline C_FIBTEM & Unit cost of FIBTEM ${ }^{\circ}$ & Triangular & 67.56 & 84.47 & 101.34 & $\begin{array}{c}\text { Biomig Materiais } \\
\text { Médico-Hospitalares Ltda. }\end{array}$ \\
\hline C_HEPTEM & Unit cost of HEPTEM ${ }^{\circ}$ & Triangular & 68.06 & 85.07 & 102.09 & $\begin{array}{c}\text { Biomig Materiais } \\
\text { Médico-Hospitalares Ltda. }\end{array}$ \\
\hline C_TP & Unit cost of the PT test & Triangular & 1.05 & 1.32 & 1.58 & SigTap; procedure 02.02.02.014-2 \\
\hline C_TTPa & Unit cost of the aPTT test & Triangular & 2.23 & 2.79 & 3.34 & SigTap; procedure 02.02.02.013-4 \\
\hline C_TCA & Unit cost of the ACT test & Triangular & 1.05 & 1.32 & 1.58 & SigTap; procedure 02.02.02.007-0 \\
\hline$C_{-} C P$ & Unit cost of the PC test & Triangular & 1.05 & 1.32 & 1.58 & SigTap; procedure 02.02.02.002-9 \\
\hline C_CFP & Unit cost of the PFC test & Triangular & 1.78 & 2.22 & 2.67 & SigTap; procedure 02.02.02.029-0 \\
\hline c_l & Cost of treatment of infections & Triangular & 5625.16 & 7031.44 & 8437.73 & (Nangino et al., 2012) \\
\hline C_LRA & Cost of treatment of acute kidney injury & Triangular & 11839.69 & 14799.61 & 17759.54 & (Ramirez et al., 2017) \\
\hline c_proc & Cost of cardiac procedures & Triangular & 16104.06 & 20130.07 & 24156.08 & (Titinger et al., 2015) \\
\hline C_RPS & Cust of reoperation for bleeding & Triangular & 16104.06 & 20130.07 & 24156.08 & $\begin{array}{c}\text { (Gunnarsson et al., 2015; Titinger } \\
\text { et al., 2015) }\end{array}$ \\
\hline C_RBC & Cost of RBC units & Triangular & 98.69 & 123.36 & 148.03 & Hemominas, 2019 \\
\hline C_FFP & Cost of FFP units & Triangular & 73.35 & 91.68 & 110.01 & Hemominas, 2019 \\
\hline c_plaq & Cost of platelet units & Triangular & 60.67 & 75.84 & 91.00 & Hemominas, 2019 \\
\hline$C_{-}$CPT & Cost of prothrombin complex unit & Triangular & 457.41 & 571.76 & 686.11 & $\begin{array}{c}\text { Ministry of Planning, search carried } \\
\text { out on } 11 / 29 / 2019, \text { via price panel, } \\
\text { for the last } 180 \text { days. }\end{array}$ \\
\hline c_fib & Cost of fibrinogen unit & Triangular & 366.97 & 458.72 & 550.46 & $\begin{array}{l}\text { Ministry of Planning, search carried } \\
\text { out on } 11 / 29 / 2019 \text {, via price panel, } \\
\text { for the last } 180 \text { days. }\end{array}$ \\
\hline
\end{tabular}

*Data from the Ministry of Health's price panel were obtained from the website paineldepreços.planejamento.gov.br/. 
9. Distribution of cost of thromboembolic events

\begin{tabular}{llcccc}
\hline Variable & Description & Distribution & $\mathbf{a}$ & $\boldsymbol{\lambda}$ & References \\
\hline C_ETE & Cost of treatment of thromboembolic events & Gamma & 525.7782 & 0.1047367 & (Safanelli et al., 2019) \\
\hline
\end{tabular}

\section{Population undergoing cardiac surgery in Brazil per year, according to data from Datasus}

SUS hospital procedures - by place of stay - Brazil

AlH approved by Year attendance

Procedure group: 04 Surgical procedures

Organization form: 040601 Cardiovascular surgery, 040603 Interventional cardiology

Period: Jan/2008-Sep/2019

\begin{tabular}{|c|c|c|}
\hline Year of service & AlH_approved & Reference \\
\hline 2008 & 113,819 & Ministry of Health \\
\hline 2009 & 122,380 & Ministry of Health \\
\hline 2010 & 128,739 & Ministry of Health \\
\hline 2011 & 138,254 & Ministry of Health \\
\hline 2012 & 144,990 & Ministry of Health \\
\hline 2013 & 148,149 & Ministry of Health \\
\hline 2014 & 152,840 & Ministry of Health \\
\hline 2015 & 152,775 & Ministry of Health \\
\hline 2016 & 156,196 & Ministry of Health \\
\hline 2017 & 160,595 & Ministry of Health \\
\hline 2018 & 164,882 & Ministry of Health \\
\hline 2019 & 171,089 & Estimated by linear regression \\
\hline 2020 & 175,472 & Estimated by linear regression \\
\hline 2021 & 179,856 & Estimated by linear regression \\
\hline 2022 & 184,239 & Estimated by linear regression \\
\hline 2023 & 188,623 & Estimated by linear regression \\
\hline 2024 & 193,006 & Estimated by linear regression \\
\hline Total & $2,675,904$ & \\
\hline
\end{tabular}

\section{Linear regression data used to estimate the population undergoing cardiac procedures}

\begin{tabular}{lc}
\hline Regression statistics \\
\hline Multipl R & 0.971932384 \\
\hline$R^{2}$ & 0.944652558 \\
\hline Adjusted R & 0.937734128 \\
\hline Standard Error & 3407.287727 \\
\hline Observations & 10
\end{tabular}

ANOVA

\begin{tabular}{lcccccc}
\hline & df & SS & MS & F & Significance $\mathbf{F}$ \\
\hline Regression & 1 & 1585193051 & 1585193051 & 136,5414599 & $2,6248 \mathrm{E}-06$ \\
\hline Residual & 8 & 92876877,22 & 11609609,65 & & & \\
\hline Total & 9 & 1678069928 & & & & \\
\hline & Coefficient & Standard Error & t Stat & P-value & Lower 95\% & Upper 95\% \\
\hline $\mathrm{b}$ & -8679056.915 & 755325.0889 & -11.49049203 & $2.98188 \mathrm{E}-06$ & -10420839.69 & -6937274.137 \\
\hline $\mathrm{a}$ & 4383.430303 & 375.1300325 & 11.68509563 & $2.6248 \mathrm{E}-06$ & 3518.378897 & 5248.481709 \\
\hline
\end{tabular}


Formula: $a x+b$

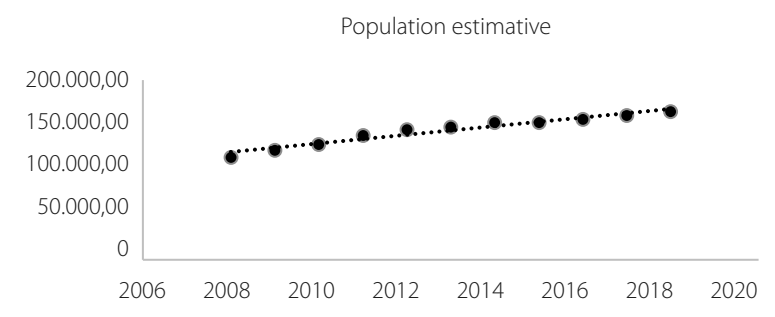

12. Comparison of the ICER with various cost-effectiveness thresholds previously proposed

\begin{tabular}{lcc}
\hline Parameter & Value in USD & Would VHAs be cost-effective at this \\
threshold?
\end{tabular}

a GDP per capita taken from the World Bank data in http://data.worldbank.org/indicator/NY.GDP.PCAP.CD. ${ }^{b}$ Converted with the OCDE Purchase Power Parity rate (2019). CER: cost-effectiveness ratio; SOC: Standard-of-care; QALY: quality-adjusted life year.

\section{REFERENCES}

Brønnum-Hansen H, Davidsen M, Thorvaldsen P; Danish MONICA Study Group. Long-term survival and causes of death after stroke. Stroke. 2001;32(9):2131-6.

Gunnarsson C, Lim S, David G, Riebman J, Martin L, Kocharian R. The Incremental cost of reoperations for bleeding events in cardiac and vascular reconstructive surgery. Value Health. 2015;18(3):A140.

Mehta RH, Honeycutt E, Patel UD, Lopes RD, Shaw LK, Glower DD, et al. Impact of recovery of renal function on long-term mortality after coronary artery bypass grafting. Am J Cardiol. 2010;106(12):1728-34.

Murphy GJ, Reeves BC, Rogers CA, Rizvi SI, Culliford L, Angelini GD. Increased mortality, postoperative morbidity, and cost after red blood cell transfusion in patients having cardiac surgery. Circulation. 2007;116(22):2544-52.

Nangino GO, Oliveira CD, Correia PC, Machado NM, Dias ATB. Impacto financeiro das infecções nosocomiais em unidades de terapia intensiva em hospital filantrópico de Minas Gerais. Rev Bras Ter Intensiva. 2012;24(4):357-61.

Oddershede L, Andreasen JJ, Ehlers L. Estimation of utility values from visual analog scale measures of health in patients undergoing cardiac surgery. Clinicoecon Outcomes Res. 2014;6:21-7.
Ramirez MG, Costa MC, Costa MDM. Análise de custo-efetividade da terapia renal substitutiva contínua versus intermitente para pacientes graves com lesão renal aguda, na perspectiva do Sistema Suplementar de Saúde brasileiro. J Bras Econ Saúde. 2017;9(2):152-8.

Safanelli J, Vieira LGDR, Araujo T, Manchope LFS, Kuhlhoff MHR, Nagel V, et al. The cost of stroke in a public hospital in Brazil: a one-year prospective study. Arq Neuropsiquiatr. 2019;77(6):404-11.

Shore-Lesserson L, Reich DL, DePerio M, Silvay G. Autologous platelet-rich plasmapheresis: risk versus benefit in repeat cardiac operations. Anesth Analg. 1995;81(2):229-35.

Titinger DP, Lisboa LA, Matrangolo BL, Dallan LR, Dallan LA, Trindade EM, et al. Cardiac surgery costs according to the preoperative risk in the Brazilian public health system. Arq Bras Cardiol. 2015;105(2):130-8.

Whiting P, Al M, Westwood M, Ramos IC, Ryder S, Armstrong N, et al. Viscoelastic point-of-care testing to assist with the diagnosis, management and monitoring of haemostasis: a systematic review and cost-effectiveness analysis. Health Technol Assess. 2015;19(58):1-228, v-vi. 